\title{
First Report of Tomato chlorotic spot virus in Hoya wayetii and Schlumbergera truncata
}

Carlye A. Baker, Florida Department of Agriculture and Consumer Services, Division of Plant Industry, Gainesville 32608; and Scott Adkins, USDA-ARS, Fort Pierce, FL 34945

Accepted by publication 15 January 2015. Published 25 February 2015.

Baker, C. A., and Adkins, S. 2015. First report of Tomato chlorotic spot virus in Hoya wayetii and Schlumbergera truncata. Plant Health Progress doi:10.1094/PHP-BR-14-0043.

Two ornamental crops were recently observed with symptoms typical of tospovirus infection in central Florida. Diseased Hoya wayetii, commonly known as porcelainflower or waxflower, plants were found in an Orange County nursery by a horticultural inspector in March 2014. Symptoms included slightly sunken chlorotic spots with necrotic margins (Fig. 1). Diseased Schlumbergera truncata (Haw.) Moran, false Christmas cactus, plants were found in a Lake County nursery by a horticultural inspector in June 2014. Symptoms included chlorotic line patterns and spots on stem segments (Fig. 2). Inclusion morphology in epidermal strips from symptomatic plants and serological testing using commercially available lateral flow immunoassay diagnostic reagents (Agdia Inc., Elkhart, IN) for Tomato spotted wilt virus (TSWV) indicated the presence of one or more tospoviruses.

Three $H$. wayetii and two $S$. truncata samples with symptoms as described above were subsequently collected from these commercial production facilities and tested for Tomato chlorotic spot virus (TCSV), Groundnut ringspot virus (GRSV), and TSWV by reverse transcription-polymerase chain reaction (RTPCR). These samples were also tested for Impatiens necrotic spot virus (INSV) using commercially available lateral flow immunoassay diagnostic reagents (Agdia Inc.). We tested for these four tospoviruses due to the similarity of reported symptoms on other plants, and also because of the recent detection of TCSV (Londoño et al. 2012; Webster et al. 2015) and a GRSV/TCSV reassortant (Webster et al. 2011) in Florida, and the prevalence of TSWV and INSV in ornamental production worldwide. Total RNA was extracted (RNeasy Plant Mini Kit, Qiagen, Valencia, CA) and tested by RT-PCR with TCSV-specific primers designed to amplify a 530-bp portion of the nucleocapsid (N) gene (TCSVNv2/TCSV-Nvc2), an 1141 bp portion of the glycoprotein precursor $\left(\mathrm{G}_{\mathrm{N}} \mathrm{G}_{\mathrm{C}}\right)$ gene $(\mathrm{GLY} 3-\mathrm{v} / \mathrm{GLY} 3-\mathrm{vc})$ or a 1011 bp portion of the RNA-dependent RNA polymerase (L) gene (TCSV3'Lv/TCSV-3'Lvc) previously described (Webster et al. 2011, 2013). Primers designed to amplify an $889 \mathrm{bp}$ portion of the movement protein (NSm) gene (TCSV-NSmFullv 5'ATGTTGACAYTTTTCGGCAGCAAVAAACC-3'; TCSVNSmvc 5'-GTTTGGCAATGTTATCACAAACACC-3') were also used. Amplicons of the expected sizes were produced with all four TCSV primer sets from all $H$. wayetii and $S$. truncata samples. Primers specific for the N gene of TSWV (Adkins and Rosskopf 2002) or GRSV (Webster et al. 2011) did not amplify products from any samples. No positive reactions were observed with INSV lateral flow immunoassays.

Four TCSV amplicons $\left(\mathrm{N}, \mathrm{G}_{\mathrm{N}} \mathrm{G}_{\mathrm{C}}, \mathrm{NSm}\right.$, and $\left.\mathrm{L}\right)$ from two samples (one $H$. wayetii and one $S$. truncata) were gel-purified and cloned (pGEM-T, Promega, Madison, WI). Six clones of each amplicon were sequenced in both directions, Vector NTI Advance software (Version 11, Invitrogen, Carlsbad, CA) was used for consensus construction and sequences were submitted to GenBank (KP063314 to KP063321). All four genes showed 97$100 \%$ nucleotide identity with the corresponding genes of TCSV isolates described from Florida, Puerto Rico, Dominican Republic, Brazil, and South Africa.

To the best of our knowledge, this is the first report of TCSV infection of $H$. wayetii and $S$. truncata from any location, although other tospoviruses are known to infect these and related plant species. For instance, Capsicum chlorosis virus has been reported to infect other Hoya species in Hawaii and Australia (Melzer et al. 2014; Persley et al. 2006), and TSWV and/or INSV has been reported to infect Hoya species and S. truncata (Parrella et al. 2003 and references therein). The identification of these two diverse plant species as the first reported natural ornamental hosts of TCSV has implications for TCSV epidemiology and management in ornamental and vegetable crops, which frequently share production space. TCSV infection of ornamentals will also likely lead to further geographic spread of this emerging tospovirus. 

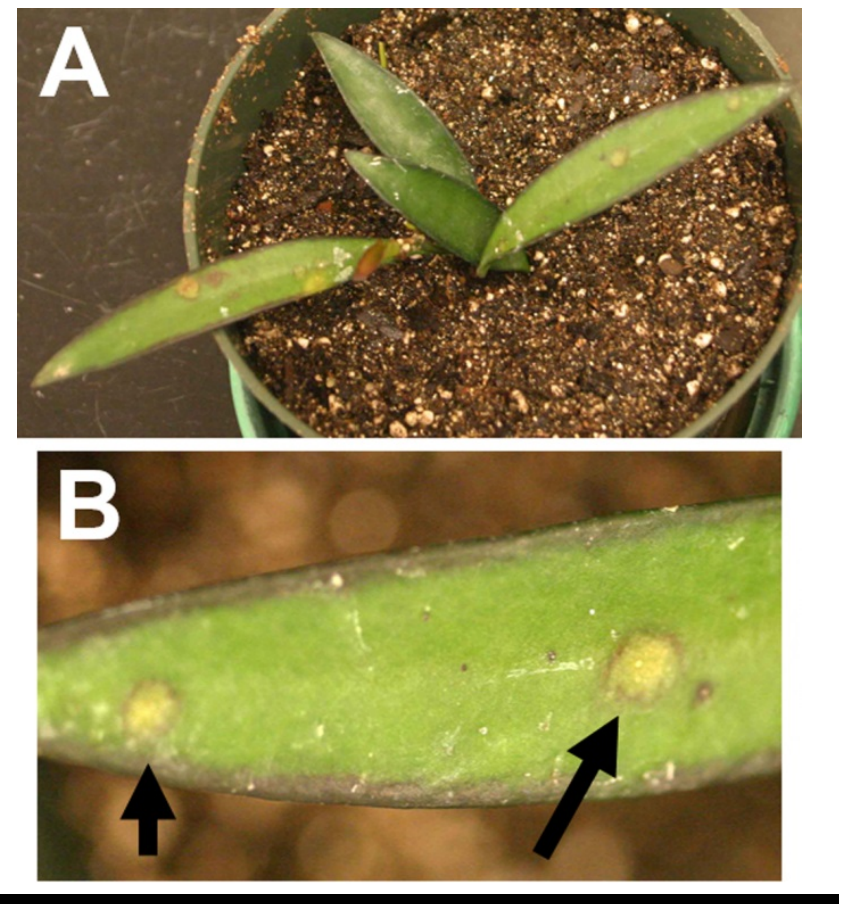

FIGURE 1

Symptoms of Tomato chlorotic spot virus infection of Hoya wayetii (porcelainflower or waxflower) include (A) slightly sunken chlorotic spots with necrotic margins. Detail (B) of a single leaf with two chlorotic spots (indicated with arrows) with necrotic margins.

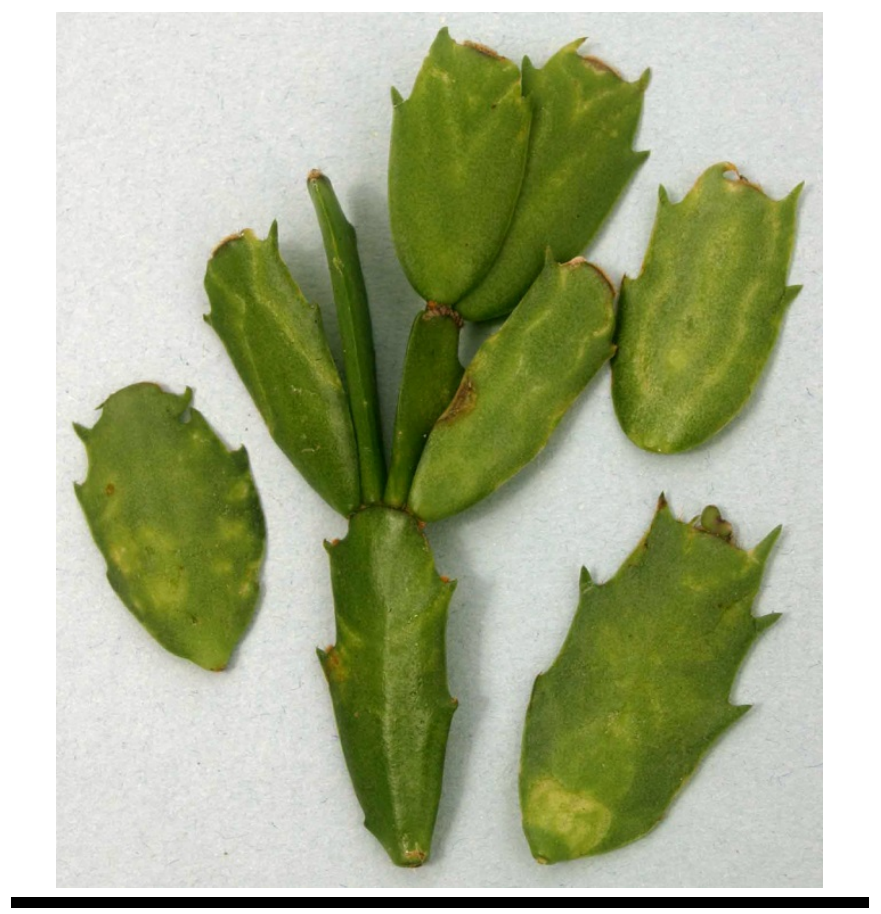

FIGURE 2

Symptoms of Tomato chlorotic spot virus infection of Schlumbergera truncata (false Christmas cactus) include chlorotic line patterns and spots on stem segments.

\section{LITERATURE CITED}

Adkins, S., and Rosskopf, E. N. 2002. Key West nightshade, a new experimental host for plant viruses. Plant Dis. 86:1310-1314.

Londoño, A., Capobianco, H., Zhang, S., and Polston, J. E. 2012. First record of Tomato chlorotic spot virus in the USA. Trop. Plant Pathol. 37:333338.

Melzer, M. J., Shimabukuro, J., Long, M. H., Nelson, S. C., Alvarez, A. M., Borth, W. B., and Hu, J. S. 2014. First report of Capsicum chlorosis virus infecting waxflower (Hoya calycina Schlecter) in the United States. Plant Dis. 98:571.

Parrella, G., Gognalons, P., Gebre-Selassiè, K., Vovlas, C., and Marchoux, G. 2003. An update of the host range of Tomato spotted wilt virus. J. Plant Pathol. 85:227-264.

Persley, D. M., Thomas, J. E., and Sharman, M. 2006. Tospoviruses - an Australian perspective. Australas. Plant Pathol. 35:161-180.

Webster, C. G., Reitz, S. R., Perry, K. L., and Adkins, S. 2011. A natural M RNA reassortant arising from two species of plant- and insect-infecting bunyaviruses and comparison of its sequence and biological properties to parental species. Virology 413:216-225.

Webster, C. G., Estévez de Jensen, C., Rivera-Vargas, L. I., Rodrigues, J.-C. V., Mercado, W., Frantz, G., Mellinger, H. C., and Adkins, S. 2013. First report of Tomato chlorotic spot virus (TCSV) in tomato, pepper and Jimsonweed in Puerto Rico. Plant Health Progress doi:10.1094/PHP2013-0812-01-BR.

Webster, C. G., Frantz, G., Reitz, S. R., Funderburk, J. E., Mellinger, H. C., McAvoy, E., Turechek, W. W., Marshall, S. H., Tantiwanich, Y., McGrath, M. T., Daughtrey, M. L., and Adkins, S. 2015. Emergence of Groundnut ringspot virus and Tomato chlorotic spot virus in vegetables in Florida and the southeastern United States. Phytopathology 105:388-398. doi:10.1094/PHYTO-06-14-0172-R 